\title{
Cytotoxicity, Antioxidants and Antimicrobial Activities of Lipids Extracted from Some Marine Algae
}

\author{
El Baz FK' ${ }^{1}$, El-Baroty GS ${ }^{2}$, Ibrahim AE¹ and Abd El Baky HH $^{1 *}$ \\ ${ }^{1}$ Plant Biochemistry Department, National Research Centre, Dokki, Cairo, Egypt \\ ${ }^{2}$ Biochemistry Department, Faculty of Agriculture, Cairo University, Cairo, Egypt
}

\begin{abstract}
The lipids of five marine algae species, i.e., two from the Red sea, Rhodophyta (Laurencia popillose, Galaxoura cylindriea), and three from the Mediterranean sea (Chlorophyta, Ulva fasciata; and Phaeophyta, Dilophys fasciola and Taonia atomaria) were evaluated as anticancer, antiviral, antimicrobial and antioxidant activities. Total lipid content was varied significantly, and the values ranged from 0.66 to $2.20 \%$. The highest lipid content was found in $U$. fasciata $(2.2 \% \mathrm{dw})$. Among fatty acids of all algae species, palmitic was dominating fatty acid and C14:0, C17:0, C18:0, C18:1, C20:4 were presented in significant levels. The polyunsaturated fatty acids C18:2, C22:5 and C20:3 were identified in most algal species.

The biological activities of algal crude lipids were assessed in vitro. The crude lipids at a concentration of $10 \mu \mathrm{g} / \mathrm{ml}$ inhibited HSV-1 virus growth (in vitro) and \% inhibition ranged from 12.5 to $74.4 \%$. While, total lipids at concentration of $20 \mu \mathrm{g} / \mathrm{ml}$ induced toxic effect in host cells. The algal lipids exhibited a potent inhibitory effect on both breast and liver human cancer cell lines with $\mathrm{IC}_{50}$ values ranged from 0.34 to $7.11 \mu \mathrm{g} / \mathrm{ml}$. All algal lipids induced remarkable antimicrobial activity Aspergillus niger and Candida albicans. Marine algal lipids exhibited moderate scavenging activity toward DPPH. radical, and high activity was found in lipids of fractionD. fasciol.
\end{abstract}

Keywords: Marine macroalgae; Algal lipids; Anticancer; Antiviral; Antibacterial; HSV-1; MCF7 Cell; HEPGcell

\section{Introduction}

Algae represent valuable sources of a wide spectrum of complex lipids with different potential applications in food, cosmetic and pharmaceutical industries [1-3]. Lipids of marine macroalgae possess antibacterial, antiviral, antitumor, antiinflammatory, antiprolierative and antioxidant activity [4-6]. Algal lipids contained high concentrations of polyunsaturated fatty acids (PUFA) and vitamins as well as bioactive molecules, e.g. phenolic and terpens compounds. Marine algae are known to be a good source of healthy food. PUFA prevent atherosclerosis development, and they reduce a frequency of heart and blood vessel diseases [4]. Bhaskar [7] found that the lipids of brown algae.

Sargassum marginatum possessed an inhibition effects against human promelocytic leukemia. Lipid extracts of Ginsens marc showed potent inhibitory activity on human hepatoma (HepG2) and breast (MCF7) cancer cell proliferation in vitro [8]. The aim of current work was to study lipid potential of some Egyptain marine algae as antiviral, anticancer, antimicrobial and antioxidant agents.

\section{Materials and Methods}

\section{Collection of algal samples}

Samples of Laurencia popillose and Galaxoura cylindriea were collected from Red Sea (Faied and Ein Al-Sokhna in Suez both in April 2007). Ulva fasciata and Taonia atomaria were collected from the Mediterranean Sea from Abu-Qir near Alexandria in 2007 and Dilophys fasciola from Marsa Matrouh in 2005. All algal sample were washed several times with tap water and then left in air for dryness. Samples were grinded and stored in glass containers at room temperature for further experiments.

\section{Identification of algae species}

After preparation of herbarium specimens of the algae species, they were identified by Dr. Rauhaiya Abdul-Latif, Professor of Botany Department of Botany, Faculty of Science, El-Azhar University, to whom the authors are very indebted.

\section{Extraction and determination of total lipids}

Total lipids of marine algae ( $100 \mathrm{~g}$ ) were extracted according to the method described by Roughan and Bratt [9].

\section{Identification of algal lipid fatty acids}

The algal lipids were subjected to direct transmethylation in $1.5 \%$ sulfuric acid: methanol at $95^{\circ} \mathrm{C}$ for $2 \mathrm{~h}$ [10]. Fatty acid methyl esters were analyzed by gas chromatography (Perkin Elmer Auto system XL) equipped with a flame ionization detector and fused silica capillary column (DB-5 (American) $60 \mathrm{~m} \times 0.32 \mathrm{~mm}$, i.d.) with a film thickness of $0.25 / 25 \mu \mathrm{m}$. The column temperature was initially set up at $150^{\circ} \mathrm{C}$ and gradually increased at rate of $3^{\circ} \mathrm{C} / \mathrm{min}$ up to $250^{\circ} \mathrm{C}$. The injector and detector temperatures were 230 and $250^{\circ} \mathrm{C}$ respectively. The helium was used as a carrier gas at $1 \mathrm{ml} / \mathrm{min}$. The split ratio was $1 / 100$. Fatty acids were identified by comparison between retention times of samples and with those of methyl fatty acid standard mixture ( Sigma, $>99 \%$ purity by GLC).

*Corresponding author: Abd El Baky HH, Plant Biochemistry Department National Research Centre, Dokki, Cairo, Egypt, Tel: +20 2 33371211; E-mail: abdelbakyh@hotmail.com

Received October 19, 2014; Accepted October 31, 2014; Published November 03, 2014

Citation: El Baz FK, El-Baroty GS, Ibrahim AE, Abd El Baky HH (2014) Cytotoxicity Antioxidants and Antimicrobial Activities of Lipids Extracted from Some Marine Algae. J Aquac Res Development 5: 284. doi:10.4172/2155-9546.1000284

Copyright: $\odot 2014$ El Baz FK, et al. This is an open-access article distributed under the terms of the Creative Commons Attribution License, which permits unrestricted use, distribution, and reproduction in any medium, provided the original author and source are credited. 


\section{Biological evaluation of algal lipids}

Preparation of algal extract for biological bioassays: The algal lipids $(100 \mathrm{mg})$ of lipids were dissolved in $10 \mathrm{ml}$ of DMSO in water $(90: 1, v / v)$ and kept at $4^{\circ} \mathrm{C}$ until used, appropriate dilution of solution were used in each assay.

Antiviral screening of algal lipids: Algal lipids were evaluated as antiviral against herps simplex virus type 1 (HSV-1). The virus was obtained from Virology Laboratory, Water Pollution Research Department National Research center (NRC), Egypt. The virus was propagated in virocell cultures. Inhibition \% of virus was calculated as plaque reduction as a result of being subjected to a given extracts [11].

Antitumor activity of algal lipids: Potential antitumor activity of algal lipids was evaluated using the method of Skehan [12]. Human HEPG2 (liver carcinoma cell lines) and MCF7 (breast carcinoma cell lines) cells were plated in 96 multiwell plate for $24 \mathrm{~h}$ before treatment with the algal lipids to allow attachment of cells to the wells of the plate. Lipids and antitumor reference drug (Novantron) were added at serial concentrations to cell monolayer. After incubation for $48 \mathrm{~h}$ at $37^{\circ} \mathrm{C}$ the cytotoxicity was determined spectrophotometrically by measureing the developed color at $570 \mathrm{~nm}$ by ELISA reader (Tecan Sunrise absorbance reader (No. 3008746), software Magllan V.4 was used).

Antimicrobial activity of algal lipids: The antimicrobial activities of algal lipids were determined by conventional agar diffusion assay [13] using one gram positive (Bacillus subtilis NRRL B- 94) one gram negative (Escherichia coli NRRL B- 3703) bacteria, fungi (Aspergillus niger NRRL 313), and yeast (Candida albicans NRRL 477). The microbial growth inhibition zone was measured after incubation at $30^{\circ} \mathrm{C}$ by the appearance of clear microbial free inhibition zone, beginning within 24 $\mathrm{h}$ for yeast, $24-48 \mathrm{~h}$ for bacteria and $72-96 \mathrm{~h}$ for fungus.

\section{Antioxidant activity of macro algal lipids using DPPH free radical-scavenging assay}

Quantitative measurement of radical scavenging properties of algal lipids was determined according to Ye [14] method.

Ethanolic DPPH solution $(0.1 \mathrm{mM})$ was prepared, to give the initial absorbance value of 0.993 at $517 \mathrm{~nm}$. The different concentrations of lipid samples (in $0.1 \mathrm{ml}$ ) of each sample (with appropriate dilution if necessary) was added to $3.0 \mathrm{ml}$ of ethanolic DPPH solution. After incubation for $30 \mathrm{~min}$ in the dark, the absorbance was measured at $517 \mathrm{~nm}$. The percentage of DPPH which was scavenged was calculated using the following formula: Scavenging $(\%)=[1-($ A sample - A blank $/ A$ control) $] \times 100 \%$.

\section{Statistical analysis}

Data were statistically analyzed through analysis of variance (Anova) and Duncans test at 0.01 probability level [15].

\section{Results and Discussion}

\section{Lipid content of marine algae}

Results illustrated in Table 1 showed that the total lipid content (TL) of five macroalgae species (Ulva fasciata, Dilophys fasciola, Taonia atomaria, Laurencia popillose and Galaxoura cylindriea)] were ranged from 0.09 to $2.2 \%$ (D.W). Total lipids showed significant differences amongst all algae species. The maximum lipid content was found in $U$. fasciata (2.2\%) followed by D. fasciola (1.1\%) then, L. popillose $(0.81 \%)$ and T. atomaria $(0.66 \%)$. Whereas the minimum value was found in $G$. cylindriea $(0.090 \%)$. These results are in agreement with those obtained

\begin{tabular}{|c|c|}
\hline Total lipids (\% dry weight basis) & Macroalgae Species \\
\hline $2.35^{\mathrm{d}}$ & $\boldsymbol{U}$. fasciata \\
\hline $1.11^{\mathrm{a}}$ & $\boldsymbol{D}$. fasciola \\
\hline $0.09^{\mathrm{a}}$ & G. cylindriea \\
\hline $0.81^{\mathrm{c}}$ & L. papillose \\
\hline $0.66^{\mathrm{b}}$ & $\boldsymbol{T}$. atomaria \\
\hline 0.09 & LSD \\
\hline
\end{tabular}

The values represent the mean of three replicate $(n=3)$ Values in the same column with different superscript letters were significantly different $(P<0.05)$

Table 1: Total lipid contents of some marine alga.

by [16], they found that the twelve species of seaweeds which includes from Chlorophyceaean, species from Phaeophyceae (Brown algae) and species from Rhodophyceae (Red algae) had lipid values ranged from 1.33 to $4.6 \%$. In another study carried out by [17], they reported that the lipid contents of Rhodophyta species, Chlorophyta species and Phaeophyta species were ranged from 1.33 to $4.6 \%$ based on D.W. On the other hand [18] found that the macroalgal total lipid content was dependent on species specific and genetic origin. Also, accumulation of lipids in macroalgal species was dependent on climate and geography development [16].

Fatty acid composition of macroalgal lipids: Fatty acid composition of marine macroalgae under investigation is illustrated in Table 2. L. papillose had the highest plamitic acid (C16:0) content (59.35\%) followed by G. cylindria (49.4\%), T. atomaria (36.27\%) and D. fasciola (32.58\%). While, $U$. faciata had the minimum C16:0 content (19.2\%).

It is very interesting that, all macroalgae species under investigation had an odd fatty acid margaric acid (C17:0). U. fasciata had the highest margaric acid content $(16.03 \%)$ followed by $L$. papillose (8.1\%). Moreover, all marine macroalgal had high content of long chain polyunsaturated fatty acids such as eicosatrienoic (C20:3) and docosapentaenoic (C22:5). However, all macroalgal species contained a low amounts of docosapentaenoic (C22:5) except $T$. atomaria (11.89\%). Hence, the predominant fatty acid is dependent on the marine algae species. The highest content of eicosatrienoic (C20:3) was detected in $U$. fasciata $(54.41 \%)$ and oleic acid (C18:1) was abundant in D. fasciola (37.49\%) (Table 3).

These results are in agreement with those obtained by Shehnaz [19], who found that the major fatty acid of $U$. fasciata was palmitic acid (16:0) (50\%) followed by oleic acid (18:1) (12.5\%), margaric acid (17:0) (9-10\%) and stearic acid (18:0) (4\%). Orhan [20] found that palmitic and oleic acids were the most abundant fatty acids in several of marine algae. Among all lipid extracts analyzed, H. scoparia contained capric acid, however myristic acid was found in $C$. fracta and $V$. sessilis, which present in freshwater origin. Fatty acid composition of $\mathrm{H}$. incrassate lipids were found to be rich of C16:0, C18:1, C 20:1, C20:3, C24:0 and (Lignoceric) C24:1 (Nervonic) fatty acid [21].

\section{Biological evaluation of marine macroalgal lipids}

Antiviral activity for marine algal crude lipid extracts against HSV-1: Table 4 showed the antiviral potential of marine algal lipids against HSV-1. The maximum inhibition of HSV-1 was recorded for the lipid extract of T. atomaria (74.4\%) followed by D. fasciola (72\%) and G. cylindriea $(72 \%)$ at a concentration of $10 \mu \mathrm{g} / \mathrm{ml}$. The complete inhibition effect was observed in T. atomaria, D. fasciola and G. cylindriea lipids at the concentration of $20 \mu \mathrm{g} / \mathrm{ml}$. 
Citation: El Baz FK, El-Baroty GS, Ibrahim AE, Abd El Baky HH (2014) Cytotoxicity, Antioxidants and Antimicrobial Activities of Lipids Extracted from Some Marine Algae. J Aquac Res Development 5: 284. doi:10.4172/2155-9546.1000284

Page 3 of 5

\begin{tabular}{|c|c|c|c|c|c|}
\hline \multicolumn{6}{|c|}{ Algal strain } \\
\hline & & \multicolumn{2}{|c|}{ Mediterranean sea } & \multicolumn{2}{|c|}{ Red sea } \\
\hline & U. fasciata & T. atomaria & D. fasciola & L. papillose & G. cylindriea $p$ \\
\hline Myristic acid $\left(\mathrm{C}_{14: 0}\right)$ & - & 2.84 & 11.04 & 10.33 & 11.29 \\
\hline Plamitic acid $\mathrm{C}_{16: 0}{ }^{*}$ & 19.20 & 36.27 & 32.58 & 59.35 & 49.40 \\
\hline palmitoleic acid $\mathrm{C}_{16: 1}$ & - & 0.74 & 4.06 & 5.82 & 8.39 \\
\hline Margaric acid $\left(C_{17: 0}\right)$ & 16.03 & 0.65 & 5.72 & 8.06 & 0.77 \\
\hline Stearic $\left(\mathrm{C}_{18: 0}\right)$ & 5.39 & 14.22 & 2.07 & 2.13 & 4.56 \\
\hline Oleic acid $\left(\mathrm{C}_{18: 1}\right)$ & 3.41 & 11.50 & 37.49 & 5.11 & 7.41 \\
\hline Linoleic $\left(C_{18: 2}\right)$ & - & 21.34 & - & 9.48 & 9.01 \\
\hline Eicosatrienoic $\left(\mathrm{C}_{20: 3}\right)$ & 54.41 & 0.55 & 5.31 & - & 4.99 \\
\hline Docosapentaenoic $\left(\mathrm{C}_{22: 5}\right)$ & 1.56 & 11.89 & 1.69 & 0.25 & 1.92 \\
\hline Saturated FAs $\%$ & 40.62 & 53.98 & 51.41 & 79.87 & 66.52 \\
\hline MUFAs $\%$ & 3.41 & 12.24 & 41.55 & 10.93 & 15.8 \\
\hline PUFAs \% & 55.97 & 33.78 & 7.00 & 9.73 & 15.92 \\
\hline
\end{tabular}

FA, fatty acid; MUFAs, monounsaturated fatty acids; PUFAs,Polyunsaturated fatty acids

Table 2: Fatty acid composition of some marine algal lipids.

\begin{tabular}{|c|c|c|}
\hline & \multicolumn{2}{|c|}{ Viral inhibition (\%) } \\
\hline Algal Species & 10 & 20 \\
\hline U. fasciata & 53.12 & \\
\hline T. atomaria & 74.40 & \\
\hline L. papillose & 12.50 & \\
\hline G. cylindriea & 72.00 & \\
\hline D. fasciola & 72.00 & $T$ \\
\hline
\end{tabular}

$\mathrm{T}$ : Toxicity=complete inhibition

Table 3: Antiviral activity of crude lipids extracted from some marine algae against HSV-1.

\begin{tabular}{|c|c|c|c|c|c|c|}
\hline \multicolumn{7}{|c|}{ Inhibition \% } \\
\hline \multirow{2}{*}{$\begin{array}{c}\text { Algal lipid } \\
\text { concentration }(\mu \mathrm{g} / \mathrm{ml})\end{array}$} & \multicolumn{5}{|c|}{ Algal Species } & \multirow{2}{*}{$\begin{array}{c}\begin{array}{c}\text { Reference } \\
\text { control }\end{array} \\
\text { Novantron }\end{array}$} \\
\hline & U. fasciata & T. atomaria & D. fasciola & L. papillose & G. cylindriea & \\
\hline 1.0 & $28.3^{a}$ & $77.24^{\mathrm{a}}$ & $59.12^{a}$ & $17.21^{\mathrm{a}}$ & $22.18^{\mathrm{a}}$ & 42.734 \\
\hline 2.5 & $48.6^{a}$ & $77.21^{\mathrm{a}}$ & $62.96^{a}$ & $47.27^{\text {a }}$ & $52.17^{a}$ & 52.81 \\
\hline 5.0 & $52.15^{\mathrm{a}}$ & $80.24^{a}$ & $73.9^{b}$ & $65.66^{b}$ & $65.73^{a}$ & 52.81 \\
\hline 10.0 & $51.62^{b}$ & $82.34^{a}$ & $74.84^{b}$ & $74.01^{\circ}$ & $69.01^{b}$ & 52.81 \\
\hline $\mathrm{IC}_{50}$ & 7.18 & 0.34 & 2.55 & 2.95 & 1.61 & 1.40 \\
\hline LSD & 13.12 & 7.81 & 9.49 & 11.90 & 23.02 & \\
\hline
\end{tabular}

The mean $(\mathrm{n}=3)$ difference was significant at $P \leq 0.05$

Table 4: Antitumor activity of some marine algal crude lipid extract against MCF7 after $48 \mathrm{~h}$ incubation period.

These results are similar to that obtained by Chirasuwan [22], they found that lipid extracts of S. platensis possessed antiviral activity against HSV-1 with an IC50 value of $25.1 \mu \mathrm{g} / \mathrm{ml}$. On the other hand, the 1- docosanol (C22:0) was found to inhibit viral replication by interfering with the early intracellular events surrounding viral entry into target cells. It is possible that interaction between the highly lipophilic compound and components of target cell membranes renders such target cells less susceptible to viral fusion and/or entry.

If this mechanism proves to be correct, 1-docosanol (C22:0) may provide a broad spectrum activity against many different viruses, especially those with lipid-containing envelopes [23]. Pope [24] reported the C22:0, n-docosanol exhibited in vitro antiviral activity against several lipid enveloped viruses including herps simplex viruses 1 and 2 by a mechanism that interferes with normal viral entry into target cells.

Antitumor activity of marine algal lipids extract against human breast carcinoma (MCF-7) and hepato carcinoma cells (HEPG2): Antitumor potential of macroalgal lipids was evaluated against breast carcinoma cell line (MCF-7) and hepato carcinoma cells (HepG2) at different concentrations of algal lipids $(1,2.5,5$ and $10 \mu \mathrm{g} / \mathrm{ml})$ and tumor cells viability after $48 \mathrm{~h}$ incubation and the results are presented in Tables 5 and 6 . The inhibition \% of algal crude lipids on MCF-7 and HepG2 cells was ranged between 17.21- 82.34\% and 24.0- $61.0 \%$, respectively. The T. atomaria crude lipids showed the highest inhibition \% at all concentrations ranged from 77.21 to $82.34 \%$. However, T. atomaria lipid extract had the lower IC50 value against MCF-7 cell line $(0.34 \mu \mathrm{g} / \mathrm{ml})$ compared with that of the antitumor drug Novantron (1.40). While, G. cylindriea lipids caused high potential antitumor activity with IC50 of $4.09 \mu \mathrm{g} / \mathrm{ml}$ against HepG2 cell, compared to Novantron antitumor drug $(\mathrm{IC} 50=4)$. The results of the present study demonstrated that the marine algal lipids of $T$. atomaria showed significantly higher antitumor activity against human breast carcinoma (MCF-7) and the human hepato carcinoma (HepG2) compared with that of Novantron antitumor drug. Similar results were obtained from lipids of brown algae Sargassum marginatum, which possessed an inhibition effect against human pro-melocytic leukemia [7]. Lipid extracts of Ginseng marc showed a potent inhibitory activity 


\begin{tabular}{|c|c|c|c|c|c|c|}
\hline \multirow{2}{*}{$\begin{array}{l}\text { Algal lipid concentration } \\
\qquad(\mu \mathrm{g} / \mathrm{ml})\end{array}$} & \multicolumn{5}{|c|}{ Algal Species } & \multirow{2}{*}{$\begin{array}{c}\text { Reference control } \\
\text { Novantron }\end{array}$} \\
\hline & U. fasciata & T. atomaria & D. fasciola & L. papillose & G. cylindriea & \\
\hline 1.0 & 24.00 & 42.00 & 35.00 & 35.00 & 41.00 & 26.10 \\
\hline 2.5 & 30.00 & 52.00 & 41.00 & 41.00 & 56.00 & 42.27 \\
\hline 5.0 & 32.00 & 58.00 & 49.0 & 49.00 & 61.00 & 47.66 \\
\hline 10.0 & 36.00 & 61.00 & 52.00 & 52.00 & 64.00 & 59.50 \\
\hline $\mathrm{IC}_{50}(\mu \mathrm{g} / \mathrm{ml})$ & 4.00 & - & 1.68 & 7.11 & 4.09 & 4.00 \\
\hline
\end{tabular}

Table 5: Antitumor activity of some marine algal crude lipid extract against HepG2 after $48 \mathrm{~h}$ incubation period.

\begin{tabular}{|c|c|c|c|c|}
\hline \multicolumn{5}{|c|}{ Inhibition zone (mm) } \\
\hline \multirow[b]{2}{*}{ Algal Species } & \multicolumn{2}{|c|}{ Bacteria } & \multirow{2}{*}{$\begin{array}{l}\text { Fungi } \\
\text { A. niger }\end{array}$} & \multirow{2}{*}{$\begin{array}{c}\text { Yeast } \\
\text { C. albicans }\end{array}$} \\
\hline & E. coli & B. subtilis & & \\
\hline U. fasciata & - & - & 8 & 13 \\
\hline T. atomaria & 11 & - & - & 15 \\
\hline L. papillose & 7 & - & 12 & 16 \\
\hline G. cylindriea & 9 & - & 10 & 12 \\
\hline D. fasciola & 13 & - & 7 & 11 \\
\hline
\end{tabular}

Table 6: Antimicrobial activities of algal crude lipid extracts at a concentration of $100 \mu \mathrm{g} / \mathrm{well}$.

\begin{tabular}{|c|c|c|c|c|c|c|c|}
\hline \multirow{3}{*}{$\begin{array}{c}\text { Algal lipid } \\
\text { concentration }(\mu \mathrm{g})\end{array}$} & \multicolumn{5}{|c|}{ Algal species } & \multirow{2}{*}{\multicolumn{2}{|c|}{$\begin{array}{l}\text { Reference } \\
\text { control }\end{array}$}} \\
\hline & \multicolumn{2}{|c|}{ Mediterranean Sea } & \multicolumn{3}{|c|}{ Red Sea } & & \\
\hline & U. fasciata & T. atomaria & D. fasciola & L. papillose & G. cylindriea & BHA & BHT \\
\hline 60 & $25.09^{a}$ & $12.17^{a}$ & $66.45^{a}$ & $28.83^{a}$ & $22.81^{\mathrm{a}}$ & $52.59^{a}$ & $51.25^{\mathrm{a}}$ \\
\hline 80 & $28.90^{\mathrm{b}}$ & $14.50^{\mathrm{a}}$ & $75.85^{b}$ & $32.81^{b}$ & $28.72^{b}$ & $72.25^{b}$ & $68.13^{b}$ \\
\hline 100 & $39.47^{c}$ & $19.17^{b}$ & $90.88^{b}$ & $35.93^{c}$ & $32.97^{c}$ & $88.22^{c}$ & $88.44^{c}$ \\
\hline LSD & 2.06 & 2.79 & 13.02 & 1.57 & 2.81 & 8.03 & 3.02 \\
\hline
\end{tabular}

The mean $(\mathrm{n}=3)$ difference was significant at $P \leq 0.05$

Table 7: Antioxidant activity of marine algae crude lipids assessed by DPPH radical.

on human hepatoma (HepG2, IC50=41.7 $\mu \mathrm{g} / \mathrm{ml}$ ) and breast (MCF-7, IC $50=54.4 \mu \mathrm{g} / \mathrm{ml}$ ) cancer cell proliferation [8]. Some macroorganisms such as mushroom lipid extract from G. sinensis possessed antitumor activity against leukemic (U937) and hepato carcinoma cells (HepG2). All these symptoms induced throughout the apoptotic changes in cells, including decreased cell volume and chromatin condensation [23].

\section{Antimicrobial activity of marine algal crude lipid extracts}

The antimicrobial potential of macroalgal crude lipids were assayed against one fungi (Aspergillus niger NRRL313), one yeast (Candida albicans NRRL477), one gram positive bacteria (Bacillus subtilis NRRL B-94) and one gram negative bacteria (Escherichia coli NRRL B-3703) Table 6 by measuring the inhibition zones (IZs) at the concentration of $100 \mu \mathrm{g} /$ well. Lipid extract of $L$. popillose had antifungal effect against $A$. niger with $12.0 \mathrm{~mm}$ IZs followed by G. cylindriea (10 mm IZs). Lipid extracts of L. popillose and T. atomaria induced antiyeast effect against C. albicans with IZs values of 16 and $15 \mathrm{~mm}$, respectively. However, lipids extract of U. fasciata and D. fasciola had a moderate activity against both microbes. $D$. fasciola lipids had the maximum antibacterial activity against E. coli (13.0 mm IZs) followed by T. atomaria (11 $\mathrm{mm}$ IZs). All macroalgal lipids extract did not show any effect against Bacillus subtilis.

The results of the present experiment showed that the algal crude lipids of L. papillose and T. atomaria induced the highest antiyeast activity, which may be attributed to the presence of unsaturated fatty acids. The results of the present study are in agreement with the findings of Ballantine [26], they found that some of the algal lipid extracts caused antifungal activity against C. albicans, gram-negative P. aeruginosa and E. coli. Ramadan [27] found that the lipid extract of Spirulina platensis induced antimicrobial activity against A. niger and
C. albicans at concentration of $48 \mu \mathrm{g} / \mathrm{disck}$, with IZs $28.3 \mathrm{~mm}$ and 21.3 $\mathrm{mm}$, respectively. In another study carried out by Patra [28], they found that the lipid extract of $E$. compressa exhibited antibacterial activity against B. subtilis and E. coli with $14 \mathrm{~mm}$ and $12 \mathrm{~mm} \mathrm{IZs,} \mathrm{respectively.}$

Desbois and Smith [29] attributed the prime target of total lipids may be due to the constituents of fatty acids which may disrupting the electron transport chain and oxidative phosphorylation of microbe in addition to its interference with cellular energy production. Moreover, fatty acids action may be resulted from the inhibition of enzyme activity, impairment of nutrient uptake, generation of peroxidation and autooxidation degradation products, or direct ana lysis of bacterial cells.

\section{Antioxidant activity of marine algal crude lipid extracts}

The antioxidant effects were evaluated by scavenging of 2, 2 diphenyl-picryl-hydrazyl (DPPH.) radical as shown in (Table 7). Most of the macroalgal lipid extracts possessed the ability of scavenging of DPPH. radical with different degrees. The scavenging \% was ranged from 12.17 to $90.88 \%$ at the concentration of $100 \mu \mathrm{g}$ algal lipids. The highest antioxidant effect was obtained with $D$. fasciola (90.88\%) total lipids. Whereas, the lipid extracts of $U$. fasciata (39.47\%), L. papillose (35.93\%), G. cylindriea (32.97\%) and T. atomaria (19.17\%) exhibited the weakest DPPH. radical scavenging activity. Shanab [30] found that S. dentifolium extracted with di-chloromethane induced the greatest free radical (DPPH) scavenging activity $(86 \%)$ at concentration $100 \mu \mathrm{g} /$ ml. Lipids of L. papillosa caused the greatest anti-lipid peroxidation efficiency (87\%) comparing with silymarin (96\%) as a standard antioxidant agent. However, the highest antioxidant activity of crude lipids of several macroalgae species extracted with hexane may be due to the presence of many substances such as carotenoids, soluble lipids, phenolic compounds, steroids and terpenoids [31]. Ramadan 
Citation: El Baz FK, El-Baroty GS, Ibrahim AE, Abd El Baky HH (2014) Cytotoxicity, Antioxidants and Antimicrobial Activities of Lipids Extracted from Some Marine Algae. J Aquac Res Development 5: 284. doi:10.4172/2155-9546.1000284

Page 5 of 5

[25] found that the Spirulina platensis lipids exhibited free radical scavenging activity (from 21 to $27 \%$ ) against $\mathrm{DPPH}$ with various degrees.

In conclusion, crude lipids of algal species under investigation was biologically evaluated. The results indicated that the algae showed different biological properties as antitumor, antioxidant, antimicrobial and antivirus with various degrees. Most of the algal crude lipids possessed an inhibition effect against human hepato carcinoma (HepG2) and human breast carcinoma (MCF-7), specially T. atomaria which induced the greatest antitumor activity with IC50 0.34 and 1.68 $\mu \mathrm{g} / \mathrm{ml}$, respectively. Moreover, it is worth mentioned that the crude lipids of $D$. fasciola showed a significant higher scavenging radical activity against the DPPH (90.88). The antioxidant activity may be due to the presence of lipophilic antioxidants (total carotenoids and a-tocopherol, phenolic and terpenoid compounds) and PUFAs. The highest antimicrobial activity of algal crude lipids was found in $T$. atomaria and L. papillose against $A$. niger and C. albicans, which might be attributed to the presence of different polyunsaturated fatty acids, phenolic and flavonoids.

\section{References}

1. Hossain Z, Kurihara H, Hosokawa M, Takahashp K (2005) Growth inhibition and induction of differentiation and apoptosis mediated by sodium butyrate in Caco-2 cells with algal glycolipid. In Vitro Cell Dev Biol Anim 41: 154-159.

2. Abd El Baky HH, El Baz FK, El-Baroty GS (2009) Natural preservative ingredient from marine alga Ulva lactuca $L$. International J Food Sci Technol 44: 1688-1695

3. Abd El Baky HH, El-Baroty GS (2013) The potential use of microalgal carotenoids as dietary supplements and natural preservative ingredient. J Aquatic Food Product Technol 4: 392-406.

4. Gerasimenko IN, Busarova GN, Moiseenko PO (2010) Age dependent changes in the content of lipids, fatty acids, and pigments in brown alga Costaria costata. Russ J Plant Physiol 57: 62-68.

5. Goecke F, Hernández V, Bittner M, González M, Becerra J, Silva M (2010) Fatty acid composition of three species of Codium (Bryopsidales, Chlorophyta) in Chile. Revista de Biología Marina y Oceanografía 45: 325-330.

6. El Baz FK, El-Baroty GS, Abd El Baky HH, Abd El-Salam OI, Ibrahim EA (2013) Structural characterization and biological activity of sulfolipids from selected marine algae. Grasasy Aceites 64: 561-571.

7. Bhaskar N, Hosakawa N, Miyashita K (2004) Growth inhibition of human promyelocytic Leukemia (HL-60) cells by lipid extract of marine algae Sargassum marginatum (Fucales, phaeophytae) harvested off Goa (west coast of India) with special reference to fatty acid composition. Indian Journal Marine Science 33: $335-360$.

8. Lee SD, Yoo G, Chae HJ, Hwang YK, Hwang WI, et al. (2009) Lipid-soluble extracts as the main source of anticancer activity in ginseng and Ginseng marc. J Amer Oil Chemists Soci 86: 1065-1071.

9. Roughan PG, Bartt RD (1968) Quantitative analysis of sulfolipid (Sulfoquinovosyl Diglyceride) and galactolipids (Monogalactosyl and Digalactosyl Diglycerides) in plant tissues. Anal Biochem 22: 74-88.

10. Luddy FE, Beerford RA, Riemen SRW (1960) Direct conversion of lipid components to their fatty acid methyl esters. J Amer Oil Chemis Soci 37: 447451.

11. Tebas P, Stabell EC, Olivo PD (1995) Antiviral susceptibility testing with a cell line which expresses beta-galactosidase after infection with herpes simplex virus. Antimicrob Agents Chemother 39: 1287-1291.

12. Skehan P, Storeng R, Scudiero D, Monks A, McMahon J, et al. (1990) New colorimetric cytotoxicity assay for anticancer-drug screening. J Nat Cancer Inst 82: $1107-1112$

13. Greenwood D (1983) Antimicrobial chemotherapy, Part II-Laboratory Aspects of Antimicrobial Therapy Bailliere, Tindall, London.

14. Ye H, Wang K, Zhou C, Liu J, Zeng X (2008) Purification, antitumor and antioxidant activities in vitro of polysaccharides from the brown seaweed Sargassum pallidum. Food Chemistry 111: 428-432.

15. Gomes KA, Gomes AA (1984) Statistical procedures for agricultural research. John Wiley and Sons, New York.

16. Manivannan K, Karthikai DG, Thirumaran G (2008) Biochemical composition anantharaman, seaweeds from sandapam coastal regions along southeast coast of India. Amer Euras J Bot 2: 42-51.

17. Matanjun P, Mohamed S, Mustapha MN, Muhammad K (2009) Nutrient content of tropical edible seaweeds, Eucheuma cottonii, Caulerpa lentillifera and Sargassum polycystum. J App Phycol 21: 75-80.

18. Araki S, Sakurai T, Oohuso T, Kayama M, Nisizawa K (1990) Conten of arachidonic and eicosapentaenoic acids in polar lipids from Gracilaria (Gracilariales Rodophyta). Hydrobiologyia 204: 513-519.

19. Shehnaz, L. (2003). Comparative phycochemical investigations on a variety of marine algae from Karachi coast. Ph.D. Thesis, Kar. University Seaweed Bio.

20. Orhan I, Sener B, Atici T (2003) Fatty acid distribution in the lipoid extracts of various algae. Chem Nat Com 39: 167-170.

21. Chirasuwan N, Chaiklahan R, Kittakoop P, Chanasattru W Ruengjitchatchawalya M, et al. (2009). Anti HSV-1 activity of sulphoquinovosyl diacylglycerol isolated from Spirulina platensis. Science Asia 35: 137-141.

22. Novoa VA, Andrade-Wartha RSE, Linares FA, Silva MOA, Genovese IM, et al. (2011) Antioxidant activity and possible bioactive components in hydrophilic and lipophilic fractions from the seaweed Halimeda incrassate. Braz $J$ Pharmaco 21: 53-57.

23. Katz DH, Marcelletti JF, Khalil MH, Pope LE, Katz LR (1991) Antiviral activity of 1-docosanol, an inhibitor of lipid-enveloped viruses including herpes simplex. Proc Natl Acad Sci USA 88: 10825-10829.

24. Pope LE, Marcelletti JF, Katz LR, Katz DH (1996) Anti-herpes simplex virus activity of $n$-docosanol correlates with intracellular metabolic conversion of the drug. J Lipid Res 37: 2167- 2178.

25. Zhang PJ, Zheng L, Wang JH, Magnusson KE, Liu X (2008) Lipid extract from completely sporoderm-broken germinating Ganoderma sinensis spores elicits potent antitumor immune responses in human macrophages. Phytother Res 23: $844-850$

26. Ballantine LD, Gerwick HW, Velez MS, Alexander E, Guevara P (1987) Antibiotic activity of lipid-soluble extracts from Caribbean marine algae. Hydrobiologia, 151: 463- 469.

27. Ramadan FM, Asker SMM, Zeinab IK (2008) Functional bioactive compounds and biological activities of Spirulina platensis lipids. Czech J Food Scie 26 211-222.

8. Patra JK, Patra AP, Mahapatra NK, Thatoi HN, Das S, et al. (2009) Antimicrobial activity of organic solvent extracts of three marine macroalgae from Chilika Lake, Orissa, India. Mal J Microbio 5: 128-131.

29. Desbois PA, Smith JV (2010) Antibacterial free fatty acids: activities mechanisms of action and biotechnological potential. Appl Microbiol Biotechnol 85: $1629-1642$.

30. Shanab MMS (2007) Antioxidant and antibiotic activities of some seaweeds (Egyptian isolates). International J Agric Bio 9: 220-225.

31. Shalaby EA (2008) Biochemical and Biotechnological studies on some marine algae. Cairo University, Egypt. 